\title{
Pelatihan E-Learning Dasar Massa Pandemi COVID-19 Bagi Guru SDN 43 Ampenan Kota Mataram
}

\author{
Supriadin $^{1}$, Nune Wire Panji Sakti², Elya Wibawa Syarifoeddin³. \\ ${ }^{123}$ Dosen Universitas Pendidikan Mandalika \\ E-mail: supriadin.undikma@gmail.com
}

\begin{abstract}
Abstrak. Seiring perkembangan zaman proses kegiatan belajar mengajar di kelas kini sudah memiliki banyak tantangan dan tuntutan. Salah satunya adalah semakin banyaknya jalur informasi yang dapat diakses oleh siswa hingga terkadang tidak jarang guru tertinggal jauh dari update-nya informasi yang sudah diterima oleh siswa. Oleh karena itu guru pun seolah-olah dipaksa harus mengimbanginya dengan mencari berbagai informasi tambahan menggunakan berbagai media seperti akses internet dan buku referensi terbaru dan up to date. Setelah selesai pelatihan e-learning dasar bagi guru SDN 43 Ampenan Kota Mataram yang diselenggarakan Tim Pengabdian Pada Masyarakat dalam bentuk teori dan praktik, para peserta pelatihan diharapkan mampu menyusun materi pembelajaran secara e-learning online dengan menggunakan platform Edmodo sehingga para guru tidak hanya terpaku pada satu model pembelajaran dengan menggunakan model konvensional saja. Berdasarkan uraian pelaksanaan kegiatan pengabdian ini, dapat disimpulkan bahwa partisipasi peserta pengabdian sebesar $100 \%$. Peserta aktif bertanya dan mendengarkan berbagai hal tentang materi yang telah diberikan sampai kegiatan pelatihan e-learning berakhir. Peserta mengharapkan agar program serupa diadakan kembali dengan program pelatihan e-learning tingkat lanjut dan keterampilan pembuatan media pembelajaran lainnya.
\end{abstract}

Kata Kunci: Pelatihan E-Learning Dasar

\section{PENDAHULUAN}

Seiring perkembangan zaman proses kegiatan belajar mengajar di kelas kini sudah memiliki banyak tantangan dan tuntutan. Salah satunya adalah semakin banyaknya jalur informasi yang dapat diakses oleh siswa hingga terkadang tidak jarang guru tertinggal jauh dari update-nya informasi yang sudah diterima oleh siswa. Oleh karena itu guru pun seolah-olah dipaksa harus mengimbanginya dengan mencari berbagai informasi tambahan menggunakan berbagai media seperti akses internet dan buku refrensi terbaru dan up to date.

Selain terkait dengan konten materi pembelajaran, saat ini juga telah muncul berbagai macam alternatif strategi belajar mengajar yang dapat diterapkan oleh guru, sehingga guru tidak hanya terpaku pada satu model pembelajaran saja. Mulai dari yang menggunakan metode konvensional hingga mengarah pada penggunaan media yang tergolong sangat maju. Salah satu strategi belajar yang belum banyak diterapkan saat ini adalah strategi belajar E-Learning. Salah satu definisi umum dari e-learning diberikan Gilbert \& Jones (2001), yaitu: pengiriman materi pembelajaran melalui suatu media elektronik seperti internet, intranet/extranet, satellite broadcast, audio/video tape, interactive $\mathrm{TV}, \mathrm{CD}-\mathrm{ROM}$, dan computerbased training (CBT).

E-Learning belum banyak diterapkan oleh guru karena kebanyakan guru menganggap strategi ini membutuhkan sarana dan prasarana yang cukup mahal dan kebanyakan sekolah belum fasilitas yang dianggap mendukung. Padahal pada kenyataannya, e-learning tidak harus menggunakan fasilitas yang tergolong mahal dan harus memiliki website e-learning sendiri. Saat ini sudah banyak website e-learning yang bersifat free access dan tidak berjangka waktu. Masalah ini juga dipertegas oleh Heru Suhartanto (2010) yang merincikan tentang beberapa faktor yang mendukung e-learning sudah cukup layak untuk dipakai di sekolah Indonesia : 1) Siswa tingkat SD, SMP dan SMA sudah sangat pandai memanfaatkan TIK dalam aktifitas sehari-hari. 2) Banyak sekolah 
telah memiliki perangkat komputer, namun hanya digunakan sebagai perangkat administrasi saja. 3) Telah tersedianya beberapa sistem pendukung e-learning, bahkan sudah banyak yang tersedia dalam bentuk open source atau juga yang gratis seperti Moodle.

Terkait dengan beberapa faktor di atas, salah satu akses website e-learning yang dapat dimanfaatkan secara tidak berbayar adalah Edmodo. Edmodo adalah website e-learning tidak berbayar yang dapat dimanfaatkan oleh guru untuk menjadi salah satu media dalam menerapkan strategi belajar e-learning. Namun saat ini belum banyak guru-guru yang mengetahui akan adanya media ini dan ataupun memanfaatkannya secara maksimal dalam membantu proses belajar mengajar di kelas. Kelebihan dari media website ini adalah media ini tidak hanya dapat diakses melalui media laptop saja, namun Edmodo ini juga sudah tersedi dan bisa diakses dalam bentuk aplikasi android. Hal ini bisa mempermudah guru dalam memantau kinerja dan interaksi antara guru dan siswa melalui smartphone maupun gadget berbasis android lainnya.

Penerapan strategi belajar e-learning ini juga dapat membantu guru untuk menggantikan proses belajar mengajar yang ada di kelas dan dibawa menjadi interaksi dalam dunia maya melalui website e-learning Edmodo ini pada siswa. Sehingga tidak ada alasan lagi bagi siswa akan tidak memiliki aktifitas di kelas ketika guru memiliki kesibukan atau acara di luar kelas pada saat jam pelajaran.

Menurut Khan (2005), e-learning menunjuk pada pengiriman materi pembelajaran kepada siapapun, dimanapun, dan kapanpun dengan menggunakan berbagai teknologi dalam lingkungan pembelajaran yang terbuka, fleksibel dan terdistribusi. Lebih jauh, istilah pembelajaran terbuka dan fleksibel merujuk pada kebebasan peserta didik dalam hal waktu, tempat, kecepatan, isi materi, gaya belajar, jenis evaluasi, belajar kolaborasi atau mandiri. Dengan E-Learning, peserta ajar (murid) tidak perlu duduk dengan manis di ruang kelas untuk menyimak setiap ucapan dari seorang guru secara langsung. ELearning belum banyak diterapkan oleh para guru karena menganggap bahwa strategi pembelajaran ini membutuhkan biaya yang mahal. Sehingga perlu di perkenalkan platform media pembelajaran online yang mudah dan tidak berbiaya tinggi.

\section{METODE PENGABDIAN}

Strategi belajar mengajar e-learning membutuhkan berbagai macam persiapan yang harus dipersiapkan oleh guru. Dalam pelatihan ini memiliki tujuan akhir memberikan keterampilan bagi guru ekonomi dalam menyiapkan materi dan merancang proses pembelajaran ekonomi menggunakan $e$ learning berbasis online dengan menggunakan

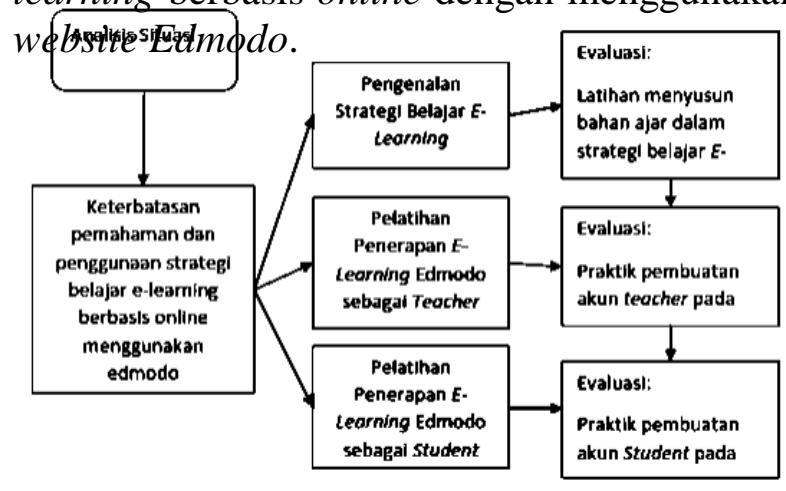

Kerangka pemecahan masalah

Pelatihan diselenggarakan dengan ceramah, tanya jawab, dan praktik.

1. Ceramah dan Tanya Jawab

Metode ini bertujuan untuk menyampaikan rangkaian materi tentang Strategi Belajar Mengajar E-Learning dan tahapan serta proses pembelajaran menggunakan Edmodo secara online.

2. Praktik

Pada sesi ini, peserta pelatihan akan dibimbing dalam menyiapkan dan menyusun proses strategi belajar mengajar E-Learning berbasis online menggunakan Edmodo.

Target kegiatan ini pengabdian masyarakat ini adalah untuk meningkat pengetahuan dan keterampilan guru ekonomi dalam memanfaatkan dan mengembangkan strategi belajar E-Learning berbasis website online menggunakan Edmodo pada guru SDN 34 Ampenan. Paradigma evaluasi ketercapaian target kegiatan adalah sebagai berikut: 


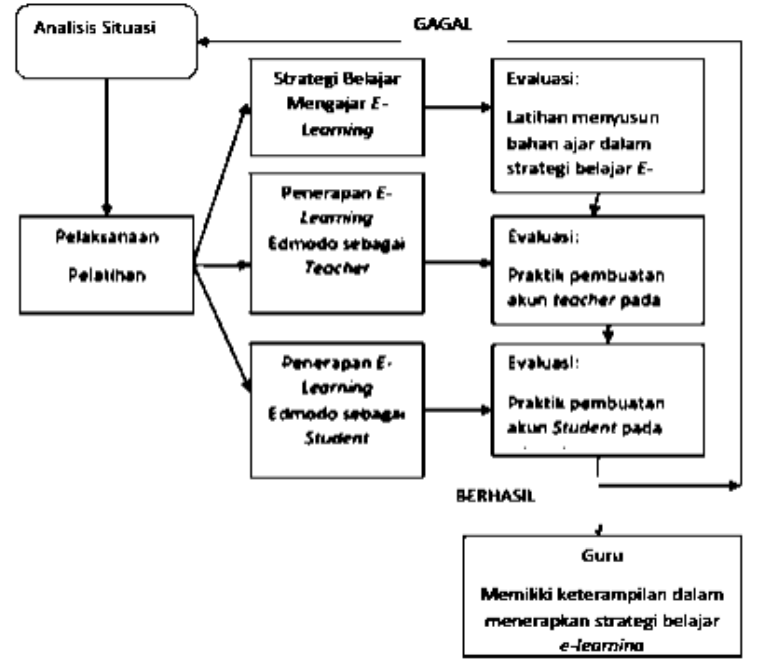

\section{HASIL DAN PEMBAHASAN}

Hasil yang diperoleh dari pengabdian ini adalah sebagai berikut.

1. Peserta yang hadir pada acara pengabdian itu sejumlah 9 orang.

2. Materi yang diberikan pada pengabdian ini meliputi materi Strategi Belajar Megajar dan Pengenalan E-Learning, Penerapan ELearning sebagai Teacher dan Penerapan E-Learning sebagai Student. Ketiga topik makalah pengabdian itu secara lengkap dapat dilihat pada lampiran.

3. Para peserta yang mengikuti pelatihan merasa senang dan puas dengan kegiatan pengabdian ini, hal ini terlihat dari ungkapan kepuasan serta keantusiasan peserta mendengarkan dan bertanya berbagai hal tentang materi yang telah diberikan oleh para pengabdi.

4. Kegiatan pengabdian ini dianggap oleh peserta sebagai sarana pengenalan dan pembelajaran mengenai e-learning dan platformnya, dan penyiapan materi $e$ learning.

5. Pada acara penutupan, hampir seluruh para peserta mengharapkan agar program serupa diadakan kembali untuk lebih memahami mengenai e-learning dan penerapan dalam Edmodo.

\section{PEMBAHASAN}

Secara umum kegiatan pengabdian ini berjalan lancar, dimulai dari kegiatan survey pendahuluan, pelaksanaan kegiatan pegabdian, sampai kepada penyusunan laporan. Berdasarkan diskusi yang diselenggarakan diperoleh kesimpulan bahwa para peserta pengabdian tersebut merasa senang dan puas. Hal ini terbukti dengan adanya permintaan dari para peserta agar kegiatan pengabdian ini tidak hanya diselenggarakan satu kali tetap harus berkelanjutan, mengingat pentingnya pembelajaran dan pengenalan e-learning bagi guru SDN 43 Ampenan Kota Mataram.

Melalui pengabdian yang berkelanjutan akan terjalin hubungan kerjasama antara guru SDN 43 Ampenan. Hubungan kerjasama dalam hal pengembangan metode pembelajaran bagi guru-guru SDN 43 Ampenan sehingga program pengabdian masyarakat dapat berjalan maksimal, yang menjadi salah satu kewajiban civitas akademika universitas.

Tingginya antusiasme peserta ditandai dengan banyaknya pertanyaan dan tingginya perhatian dari peserta sejak pengabdian dimulai hingga berakhir. Peserta pengabdian juga meminta agar pelatihan e-learning dapat dilanjutkan pada tahun mendatang dan disediakan kesempatan bagi para peserta untuk konsultasi lebih mendalam untuk semua materi pelatihan.

Faktor-faktor yang mendukung pelaksanaan pengabdian sehingga dapat terlaksana dengan lancar sebagai berikut:

1. Tingginya antusiasme peserta pengabdian yaitu guru-guru SDN 43 Ampenan kota Mataram untuk mengikuti pelatihan $e$ learning.

2. Manfaat yang besar atas tema pengabdian mengenai metode pembelajaran e-learning bagi guru-guru SDN 43 Ampenan.

3. Fasilitas dan semangat tim pengabdi yang mendukung kelancaran pengabdian.

Selain faktor pendukung, ada pula faktor penghambat yang mengakibatkan kegiatan pengabdian ini tidak mampu mencapai tujuan secara maksimal, yaitu:

1. Waktu pengabdian hanya satu hari mengakibatkan peserta kelelahan dilatih sejak jam 09.00 WIB sampai dengan jam 15.00 WIB.

2. Koordinasi antar perserta pegabdian yaitu guru-guru SDN 43 Ampenan berjalan dengan sempurna. 


\section{SIMPULAN}

Berdasarkan uraian pelaksanaan kegiatan pengabdian ini, maka dapat ditarik

kesimpulan sebagai berikut.

1. Kegiatan pengabdian ini dapat berhasil karena suluruh guru SDN 43 Ampenan hadir seluruhnya.

2. Peserta pengabdian sangat merasa senang dan puas dengan kegiatan pengabdian dan meminta agar pengabdian serupa dilaksanakan berkesinambungan mengingat pelatihan e-learning ini sangat membantu guru dalam membuat proses belajar mengajar di dalam kelas menjadi lebih bervariatif dan inovatif.

3. Berdasarkan uraian pelaksanaan kegiatan pengabdian ini, dapat disimpulkan bahwa partisipasi peserta pengabdian sebesar $100 \%$. Peserta aktif bertanya dan mendengarkan berbagai hal tentang materi yang telah diberikan sampai kegiatan pelatihan e-learning berakhir. Peserta mengharapkan agar program serupa diadakan kembali dengan program pelatihan e-learning tingkat lanjut dan keterampilan pembuatan media pembelajaran lainnya.

4. Para peserta merasa memperoleh wawasan baru tentang penggunaan e-learning dalam proses belajar mengajar, terlebih lagi $e$ learning dapat menjadi alternatif pengganti proses pembelajaran yang tidak dapat di selenggarakan di kelas.

\section{Saran}

Saran yang diajukan berhubungan dengan hasil kegiatan pengabdian ini adalah:

1. Untuk menindaklanjuti pengabdian ini diharapkan para peserta dapat kembali mengajukan permohonan pelatihan $e$ learning tingkat lanjut dan pembuatan media pembelajaran lainnya kepada Universitas Pendidikan Mandalika melalui Jurusan Pendidikan Olahraga dan Kesehatan.

2. Pelaksanaan pengabdian untuk masa mendatang sebaiknya dilakukan dengan waktu yang lebih panjang untuk dapat memasukkan materi praktik e-learning yang lebih jelas dan lebih mudah dipahami serta di praktikkan.
3. Waktu pengabdian diselenggarakan selama lebih dari 1 hari disesuaikan dengan waktu yang tersedia bagi para guru dan tema yang akan dilatihkan pada kegiatan pengabdian.

4. Koordinasi antar guru dan pengabdi lebih ditingkatkan dengan mengembangkan model pengabdian yang dapat diakses oleh semua guru dan anggota pengabdi.

\section{DAFTAR PUSTAKA}

Deni Darmawan. 2014. Pengembangan ELearning Teori dan Desain. PT. Remaja Rosdakarya: Bandung.

Heru Suhartanto. 2010. Strategi Implementasi Sistem E-Learning untuk Peningkatan Mutu Pendidikan Sekolah Indonesia. Artikel Ilmiah. Fakultas Ilmu Komputer. Universitas Indonesia

Huang, Min-Yueh, et al, 2012, "Empowering personalized learning with an interactive e-book learning system for elementary school students", Education Tech Research.

Mark Gammon. 2013. Edmodo : Microblogging for Education. Artikel yang diakses dari : https://assett.colorado.edu/edmodomicroblogging-for-education/. pada tanggal : 21 Maret 2021.

Nur Hadi Waryanto dan Nur Isnaini. 2013. Tingkat Kesiapan (Readiness) Implementasi E-Learning di Sekolah Menengah Atas Kota Yogyakarta. EJurnal : Pendidikan Matematika dan Sains, Tahun I, No. 2. Desember 2013. 